\title{
Open and closed mid-front vowels in Teotitlán del Valle Zapotec
}

\section{PuZZles AND PROBLEMS}

\author{
Hiroto Uchihara ${ }^{\mathrm{a}}$ \& Ambrocio Gutiérrez ${ }^{\mathrm{b}^{*}}$
}

aUniversidad Nacional Autónoma de México: hirotouchihara81@gmail.com

bUniversity of Texas at Austin: ambrocioteo@utexas.edu

Teotitlán del Valle Zapotec ${ }^{1}$ is spoken in the community of Teotitlán del Valle, in the Central Valley of Oaxaca in the Mexican state of Oaxaca. Teotitlán Zapotec is one of the Central Zapotec languages, which belong to the Zapotecan language family within the Otomanguean language stock. Teotitlán Zapotec has two mid-front vowels, $[\varepsilon]$ and [e]. The distribution of these two mid-front vowels is conditioned by the nature of the adjacent consonants and accent and presents challenges to formal analysis due to a number of properties predictive of the distribution: the disjunctive set of consonants conditioning the alternation, the ganging effect of consonant type and syllable structure as triggers, the featural characterization of the process as raising assimilation, and asymmetries between derived and non-derived environments in the observed patterns.

\section{Background on Teotitlán del Valle Zapotec Phonology}

The syllable structure of Teotitlán del Valle Zapotec is $(C) C V$. Onset clusters are limited in Teotitlán Zapotec. The canonical root shape of Teotitlán Zapotec is monosyllabic, either closed $(C) V C$ or open $(C) V$, while affixes or clitics are canonically monosyllabic and open $(C) V$, although there are a few which end in a consonant, too $((C) V C$ or just $C)$

\subsection{Teotitlán Zapotec vowels}

Teotitlán Zapotec has seven vowel qualities $(a, \varepsilon, e, i, \dot{i}, o, u)$, although the contrast between $/ \mathrm{o} /$ and $/ \mathrm{u} /$ is marginal as in many other varieties (Smith-Stark 2003: 226, 229; Kaufman 2016: 8; Beam de Azcona et al.

\footnotetext{
${ }^{*}$ We would like to thank Ryan Bennett, Rosemary Beam de Azcona, Christian DiCanio, as well as the participants in the Phonologica group at the El Colegio de México, organized by Esther Herrera, for the discussions we had on this topic. We are also grateful to the two anonymous reviewers and the editors of Phonological Data and Analysis, especially Eugene Buckley and Matthew Gordon, for their insightful and constructive feedback. We would also like to acknowledge Carrie Gillon for proofreading the manuscript. This project has been funded by the Institute of Philological Research at the National Autonomous University of Mexico, and the project PAPIIT-IN404019, Complejidad paradigmática y tonal de las lenguas otomangues, National Autonomous University of Mexico, awarded to the first author.

${ }^{1}$ As of 2000, in Teotitlán del Valle, $78 \%$ of the total population are speakers of Zapotec, out of which the majority (92.5\%) are bilingual in Spanish (INEGI 2000).
} 
2019). The high central vowel /it/ is found in some words, but this vowel is disappearing in Teotitlán (Arellanes et al. 2014), being replaced by $/ \mathrm{u} /$. The mid-front vowels $\varepsilon$ and $e$ are the focus of this paper.

Table 1 summarizes the vowel system of Teotitlán Zapotec. The marginal, dubious phonemes are in parentheses. The table below focuses on the vowel qualities of modal (short) vowels. Long vowels and vowels with other phonation types occur with all the vowel qualities shown in the table.

Table 1: Teotitlán vowel system

\begin{tabular}{lrrrr}
\hline & Front & Central & Back \\
\hline High & i & & (i) & $\mathrm{u}$ \\
Mid & (e) & & & $\mathrm{o}$ \\
& & $\varepsilon$ & & \\
Low & & & $\mathrm{a}$ & \\
\hline
\end{tabular}

Vowel length is mostly predictable from accent and the consonant that follows. In tonic syllables, the vowel is long when followed by a lenis consonant or no consonant; otherwise, the vowel is short. However, this is not always the case, since all loanwords and some native words have a long vowel even when the tonic vowel is followed by a fortis consonant. For this reason, we consider vowel length in Teotitlán Zapotec to be marginally contrastive; vowel length is marked with a colon (:), even where length is predictable.

As in other varieties of Zapotec, Teotitlán Zapotec is "laryngeally-complex" (Silverman 1997), in that vowels contrast tonally and in terms of phonation (Munro and Lopez 1999; Smith-Stark 2003; Arellanes 2009: Ch. 3; Chávez Peón 2010). In Teotitlán Zapotec, the modal vowel /a/ contrasts with both the weakly laryngealized vowel /a/, which is realized as a creaky vowel, and the strongly laryngealized vowel $/ \mathrm{a}^{2} /$, which is realized as $\left[a^{2}\right] \sim\left[a^{2} a\right]$; we will refer to them as creaky and rearticulated vowels, respectively. Teotitlán Zapotec is tonal as other Zapotec languages and has five tones: low (a), mid (ā), high (á), rising (ă), and falling (â).

\subsection{Teotitlán Zapotec consonants}

Central Zapotec varieties exhibit a contrast between the lenis series of consonants (the first phoneme in each pair in Table 2 written using IPA symbols for voiced obstruents and singleton sonorants) and the fortis series (the second phoneme in each pair written as voiceless obstruents and geminate sonorants), like other Zapotec varieties (Nellis \& Hollenbach 1980; Jaeger 1983; Avelino 2004). The primary feature distinguishing between fortis and lenis consonants is duration, with fortis consonants being longer. As shown in Table 2, nearly all consonants have palatalized counterparts, except for the labialized velar consonants. Phonemes in parentheses are only attested in loans.

Table 2: Consonant phonemes in Teotitlán Zapotec

\begin{tabular}{|c|c|c|c|c|c|c|c|c|c|c|c|c|c|c|c|c|}
\hline \multirow[b]{2}{*}{ Plosive } & \multicolumn{2}{|c|}{ Labial } & \multicolumn{2}{|c|}{$\begin{array}{c}\text { Palatalized } \\
\text { Labial } \\
\end{array}$} & \multicolumn{2}{|c|}{$\begin{array}{l}\text { Dental/ } \\
\text { Alveolar }\end{array}$} & \multicolumn{2}{|c|}{$\begin{array}{l}\text { Palato- } \\
\text { alveolar }\end{array}$} & \multicolumn{2}{|c|}{$\begin{array}{c}\text { Palatalized } \\
\text { Alveolar }\end{array}$} & \multicolumn{2}{|c|}{ Velar } & \multicolumn{2}{|c|}{$\begin{array}{c}\text { Palatalized } \\
\text { Velar }\end{array}$} & \multicolumn{2}{|c|}{$\begin{array}{c}\text { Labialized } \\
\text { Velar }\end{array}$} \\
\hline & $\mathrm{b}$ & $\mathrm{p}$ & $b^{j}$ & $\mathrm{p}^{\mathrm{j}}$ & $\mathrm{d}$ & $\mathrm{t}$ & & & $\mathrm{d}^{\mathrm{j}}$ & $\mathrm{t}^{\mathrm{j}}$ & $\mathrm{g}$ & $\mathrm{k}$ & $\mathrm{g}^{\mathrm{j}}$ & $\mathrm{k}^{\mathrm{j}}$ & $\mathrm{g}^{\mathrm{w}}$ & $\mathrm{k}^{\mathrm{w}}$ \\
\hline Nasal & $\mathrm{m}$ & $\mathrm{m}:$ & & & $\mathrm{n}$ & $\mathrm{n}:$ & & & $\mathrm{n}^{\mathrm{j}}$ & $\mathrm{n} .^{\mathrm{j}}$ & & & & & & \\
\hline Tap/Flap & & & & & $\mathrm{r}$ & $\mathrm{r}:$ & & & & & & & & & & \\
\hline Fricative & & (f) & & & $\mathrm{z}$ & $\mathrm{s}$ & 3 & $\int$ & & $\mathrm{s}^{\mathrm{j}}$ & & $\mathrm{x}$ & & & & $\left(\mathrm{x}^{\mathrm{w}}\right)$ \\
\hline Lateral & & & & & 1 & 1: & & & $1^{j}$ & $1:^{\mathrm{j}}$ & & & & & & \\
\hline Affricate & & & & & $\mathrm{d}$ & ts & ds & t" & & & & & & & & \\
\hline Glides & & & & & & & & & $\mathrm{j}$ & & & & & & & $\mathrm{w}$ \\
\hline
\end{tabular}




\section{The phonemic status of $[\varepsilon]$ vs [e]}

The phonemic status of $[\mathrm{e}]$ and $[\varepsilon]$ in Teotitlán Zapotec is controversial, but we can tentatively conclude that $[\mathrm{e}]$ and $[\varepsilon]$ are allophones of one phoneme $/ \varepsilon /$.

\subsection{Distribution}

One of the factors conditioning the allophony is the following consonant. The data in (1-8) show the consonants triggering [e] in tonic syllables regardless of phonation type of the vowel. Verbs are listed with the habitual prefix $r(i)$-, $r a$ - or $r u$-, unless indicated otherwise.

(1) $\mathrm{j}$

ge:j $\left(\sim\right.$ ge: $\left.\mathrm{g}^{\mathrm{j}}\right) \quad$ 'ice'

[1:e? $(\mathrm{j})]$ 'blessing'

(2) _ $\mathrm{W}$

$\begin{array}{ll}\text { bě:w } & \text { 'coyote' } \\ \text { bẹ:w } & \text { 'moon' } \\ \text { be'w } & \text { 'flea' } \\ \text { gẹ:w } & \text { 'river' }\end{array}$

(3) palato-alveolar fricatives $\left(3, \int\right)$

$$
\text { mě:3 'table' }(<\text { Sp. mesa })
$$$$
\text { bé:3 'peso' (< Sp. peso) }
$$

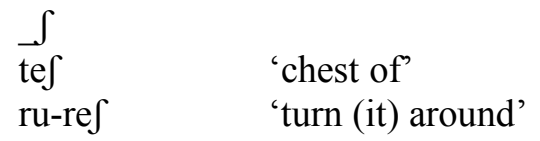

(4) palato-alveolar affricates (_ds, t)

dts

ge:ds

ge:ds

ri-be:ds

ri-lẽ्e:ds

ri-l:ę:ds

ru-k ${ }^{\mathrm{w}} \mathrm{e}: \mathrm{ds}$

ru-le:ds

'village'

'pimple'

'yell'

'get separated'

'separate (it)'

'make something sound'

'scold'

$\begin{array}{ll}\text { ty } & \\ \text { gē:t } & \text { 'thorn' } \\ \text { ri-dēt } & \text { 'get scattered' } \\ \text { ru-tèty } & \text { 'scatter' }\end{array}$

\begin{tabular}{|c|c|c|c|}
\hline $\mathrm{d}^{\mathrm{j}}$ & 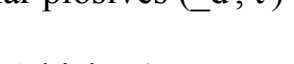 & $\mathrm{t}^{\mathrm{j}}$ & \\
\hline $\bar{b} e: d^{j}$ & 'chicken' & $\overline{\text { sé: }} \mathrm{t}^{\mathrm{j}}$ & 'oil' $(<$ Sp. aceite $)$ \\
\hline mě: $\mathrm{d}^{\mathrm{j}}$ & 'money' & $k_{e ̌ t}{ }^{j}$ & 'there is not' \\
\hline r-ę: $d^{j}$ & 'get washed' & & \\
\hline ri-ne: $\mathrm{d}^{\mathrm{j}}$ & 'get ahead' & & \\
\hline ru-n:ę: $\mathrm{d}^{\mathrm{j}}$ & 'bring forward' & & \\
\hline palatalize & $\operatorname{ar}$ nasals $\left(n^{\mathrm{j}}, \mathrm{n}^{\mathrm{j}}\right)^{2}$ & & \\
\hline$n^{\mathrm{j}}$ & & $n{ }^{\mathrm{j}}{ }^{\mathrm{j}}$ & \\
\hline re: $n^{\mathrm{j}}$ & 'blood' & xé:n: ${ }^{j}$ & 'Genaro' \\
\hline ftệ:n( $\left(^{j}\right)$ & 'of' & bēn: ${ }^{j}$ & 'person \\
\hline${ }^{l}-g^{w} e: n^{j}$ & 'get anxious' & & \\
\hline
\end{tabular}

(5) palatalized alveolar plosives $\left(\mathrm{d}^{\mathrm{j}}, \mathrm{t}^{\mathrm{j}}\right)$

\footnotetext{
${ }^{2}$ Word-final $/ \mathrm{n}^{\mathrm{j}} /$ is realized without the palatalization in some cases, but the underlying palatalization is realized

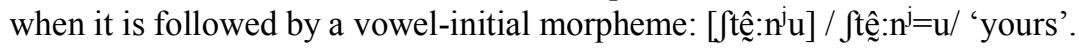


(7) palatalized laterals $\left(\_^{\mathrm{j}}, \mathrm{l}^{\mathrm{j}}{ }^{\mathrm{j}}\right)$

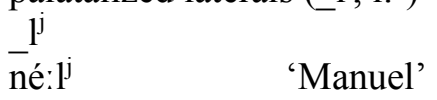

$\begin{array}{ll}{ }_{\text {ru-kēel: }}:^{j} & \text { 'hurry him up' } \\ \text { ri-gēl:. } & \text { 'hurry up' }\end{array}$

(8) palatalized velar $\left(\mathrm{k}^{\mathrm{j}}\right)$

$\begin{array}{ll}\text { xindék } & \text { 'thing' } \\ \text { ri-bēk }{ }^{j} & \text { 'put' } \\ \text { r-ek } & \text { 'get burned' } \\ \text { ru-zek } & \text { 'burn' } \\ \text { zēk } & \text { 'this way, thus' } \\ \text { rēk } & \text { 'there' }\end{array}$

On the other hand, open $[\varepsilon]$ is found in tonic syllables in complementary environments. Thus, $/ \varepsilon /$ is found in an open syllable, whether the vowel is modal, creaky or rearticulated (9); before non-palatalized alveolar consonants, namely alveolar plosives $/ \mathrm{t} /$ and /d/ (10), the alveolar affricate $/ \mathrm{ts} /(11)^{3}$, alveolar fricatives $/ \mathrm{z} /$ and $/ \mathrm{s} /(12)$, alveolar laterals $/ 1 /, / 1: /(13)$, the rhotic $/ \mathrm{r} /(14)$, the alveolar nasal /n/ (15), and finally, before labialized velar plosives $/ \mathrm{g}^{\mathrm{w}} /$ and $/ \mathrm{k}^{\mathrm{w}} /(16)$. In our database, a mid-front vowel is not attested before $/ \mathrm{b} /, / \mathrm{p} /, / \mathrm{g} /$ or $/ \mathrm{k} /$.

(9) open syllable

\begin{tabular}{|c|c|c|c|c|c|}
\hline modal & & creaky & & rearticul & lated \\
\hline $\mathrm{b} \varepsilon:$ & 'cochineal' & bę: & 'colored ant' & $\mathrm{ru}-\mathrm{z} \varepsilon^{?}$ & 'spin (thread)' \\
\hline $\mathrm{d} \varepsilon:$ & 'ash' & ra-dę: & 'get narrow' & $\mathrm{b} \vec{\varepsilon}$ & 'mushroom' \\
\hline ra-be: & 'be happy & ri-b) & 'take out' & ri-d $\varepsilon^{?}$ & 'get gathered' \\
\hline ra-de: & 'get dusty' & ri-gę: & 'get infected' & $\mathrm{k}^{\mathrm{w}} \varepsilon^{?}$ & 'side of' \\
\hline r-aknes: & 'help' & ru-stę: & 'make (it) narrow' & $11 \varepsilon^{?}$ & 'outside' \\
\hline ri-be: & 'sit down' & ndę: & 'this' & ts $\varepsilon^{?}$ & 'voice of' \\
\hline ri-d $\varepsilon:$ & 'get fetched' & rę: & 'here' & $\mathrm{z} \varepsilon^{?}$ & 'corn' \\
\hline ri-g $\bar{\varepsilon}:$ & 'curse' & & & $r-\varepsilon^{?}$ & 'drink' \\
\hline$r-\varepsilon:$ & 'go' & & & ru-g ${ }^{\mathrm{w}} \varepsilon^{?}$ & 'make (him) drink' \\
\hline est $\bar{\varepsilon}:$ & 'get up' & & & $\mathrm{ru}-\mathrm{t} \bar{\varepsilon}^{?}$ & 'gather' \\
\hline$g \varepsilon:$ & 'fetch' & & & & \\
\hline$-1 \varepsilon:$ & 'step' & & & & \\
\hline & 'REPORTATIVE' & & & & \\
\hline
\end{tabular}

(10) alveolar plosives $(\mathrm{t}, \mathrm{d})$

$\begin{array}{ll}\mathrm{t} & \\ \mathrm{g} \varepsilon t & \text { 'tortilla' } \\ \text { ri-let } & \text { 'get empty' } \\ \text { ri-l:čt } & \text { 'lower (it)' } \\ \text { bet } & \text { 'skunk' } \\ \text { let } & \text { 'place' } \\ \text { gét } & \text { 'deep' }\end{array}$

\begin{tabular}{|c|c|}
\hline$\overline{\mathrm{z} \varepsilon}: \mathrm{d}$ & 'salt' \\
\hline bé:d & 'Pedro' \\
\hline$r-\bar{\varepsilon}: d$ & 'come' \\
\hline ru-dz్s:d & 'give' \\
\hline $\mathrm{r}-\breve{\varepsilon}: \mathrm{d}(\sim \mathrm{r}-\breve{a}: \mathrm{d})$ & 'get pierced' \\
\hline ru-sq:d & 'study' \\
\hline ru-t $\varepsilon_{i}: \mathrm{d}$ & 'pass' \\
\hline
\end{tabular}

$3 / \mathrm{dz} /$ is a marginal phoneme in Teotitlán Zapotec and is only found in onset position before /i/ / (this [dzi] sequence is in free variation with [zi], [zu] or [dzu]); it cannot occur in coda position. 
(11) alveolar affricate (_ts)

bets 'brother of (a male)'

bets 'buzzard'

dets 'back of'

(12) alveolar fricatives ( $\mathrm{z}, \mathrm{s})$

$\overline{\mathrm{b}} \mathrm{z}: \mathrm{z} \quad$ 'toad'

be:z 'jaguar'

bite:z 'nest'

galge:z 'support for a party'

ge:z 'cigarette'

gq:z 'white cocoa bar'

ne:z 'road'

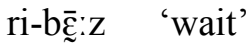

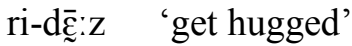

$r-\varepsilon: z \quad$ 'wash one's body'

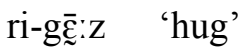

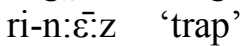

ri-re:z 'get split'

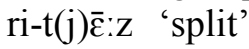

ru-g ${ }^{\mathrm{w}} \varepsilon: z$ 'wash someone's body'

ru-k ${ }^{\mathrm{w}} \overline{\varepsilon_{i}} \mathrm{z}$ 'crush'

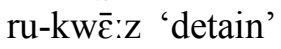

gē $: z \quad$ 'seven'

(13) alveolar laterals $\left(\_1,1:\right)$

1

be $\bar{z}: 1 \quad$ 'meat'

ge:1 'corn tree'

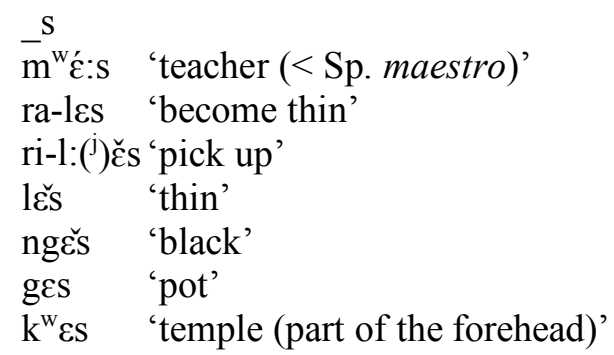

$-\mathrm{S}$

$\overline{\mathrm{m}}^{\mathrm{w}} \dot{\varepsilon}: \mathrm{s} \quad$ 'teacher $(<\mathrm{Sp}$. maestro $)$,

ra-les 'become thin'

ri-l:( $\left({ }^{j}\right) \check{\varepsilon} s$ 'pick up'

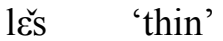

ng๕̌s 'black'

ges 'pot'

$\mathrm{k}^{\mathrm{w}} \varepsilon \mathrm{S} \quad$ 'temple (part of the forehead)'

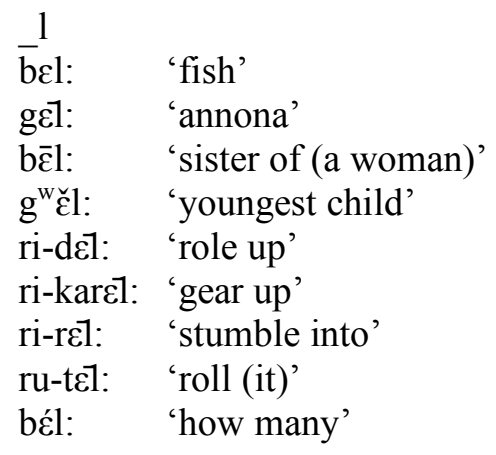

(14) $\quad$ r

$\overline{\mathrm{x}}^{\mathrm{w}} \check{\mathrm{\varepsilon}}: \mathrm{rs} \quad$ 'effort' $(<$ Sp. esfuerzo $)$

pé:r 'pear' $(<$ Sp. pera $)$

(15) _n

ř̌: $n^{4} \quad$ there (medial)'

(16) labialized velar plosives $\left(\mathrm{g}^{\mathrm{w}}, \mathrm{k}^{\mathrm{w}}\right)$

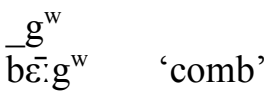

Jibe:g ${ }^{\mathrm{w}}$ 'bowl'

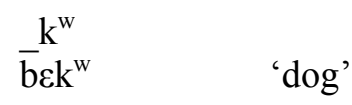

${ }^{4}$ Word-final $/ \mathrm{n} /$ is realized as a velar [ $\left.\mathrm{n}\right]$. 
In addition, open $[\varepsilon]$ is found before palatalized labials, namely $/ \mathrm{b}^{\mathrm{j}} /$ and $/ \mathrm{p}^{\mathrm{j}} /$. Recall that closed $[\mathrm{e}]$ is found instead when followed by other palatalized consonants, as we saw above. ${ }^{5}$

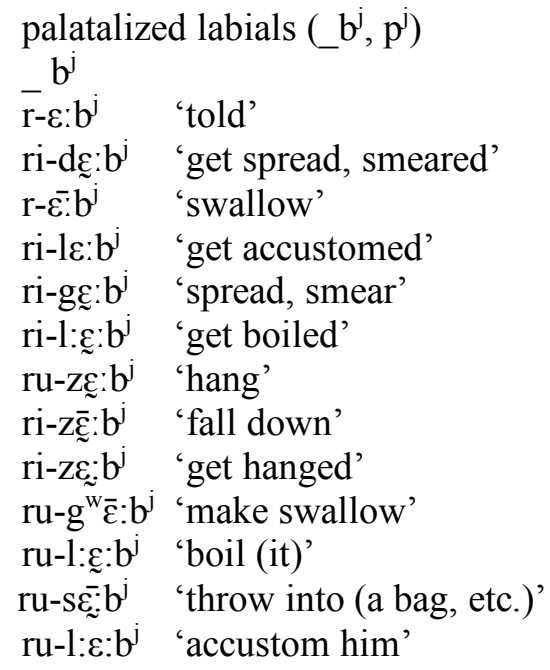

Table 3 summarizes the distribution of $[\mathrm{e}]$ and $[\varepsilon]$ in the tonic syllables discussed so far. The environments where [e] is found are shaded in grey, while those where $[\varepsilon]$ is found are unshaded. The phonemes in parentheses do not occur after a mid-front vowel in our database and thus we would not know if they trigger raising or not.

Table 3: Following consonants which predict [e]

\begin{tabular}{|c|c|c|c|c|c|c|c|c|}
\hline & Labial & $\begin{array}{c}\text { Palatalized } \\
\text { labials }\end{array}$ & Alveolar & $\begin{array}{l}\text { Palato- } \\
\text { alveolar }\end{array}$ & $\begin{array}{c}\text { Palatalized } \\
\text { alveolars }\end{array}$ & $\begin{array}{c}\text { Palatalized } \\
\text { velar }\end{array}$ & Velar & $\begin{array}{c}\text { Labialized } \\
\text { velar }\end{array}$ \\
\hline Plosive & (b), (p) & $\mathrm{b}^{\mathrm{j}}, \mathrm{p}^{\mathrm{j}}$ & $\mathrm{d}, \mathrm{t}$ & & $\mathrm{d}^{\mathrm{j}}, \mathrm{t}^{\mathrm{j}}$ & $k^{j}, g^{j}$ & $(\mathrm{~g}),(\mathrm{k})$ & $\mathrm{g}^{\mathrm{w}}, \mathrm{k}^{\mathrm{w}}$ \\
\hline Affricate & & & $(\mathrm{dz}), \mathrm{ts}$ & ds, t 5 & & & & \\
\hline Fricative & & & $\mathrm{z}, \mathrm{s}$ & $3, \int$ & $\left(\mathrm{s}^{\mathrm{j}}\right)$ & & & \\
\hline Liquid & & & $\begin{array}{l}\text { 1, 1: } \\
\text { r, (r:) }\end{array}$ & & $1^{\mathrm{j}}, 1:^{\mathrm{j}}$ & & & \\
\hline Nasal & $(\mathrm{m}),(\mathrm{m}:)$ & & $\mathrm{n},(\mathrm{n}:)$ & & $n^{j}, n:{ }^{j}$ & & & \\
\hline Glide & & & & & $\mathrm{j}$ & & & $\mathrm{w}$ \\
\hline
\end{tabular}

The issue that arises here is how to define the environments where [e] is found, in particular, which phonological feature(s) captures the class of palato-alveolars, palatalized alveolars and velars, and /w/, all of which predict [e].

One proposal is to generalize environments in terms of the features [+high, -labial], that is any nonlabial [+high] consonants, and /w/. ${ }^{6}$ Under this approach (and others using standard articulatory-based features), /w/ cannot be unified with other consonants, and the rule has to be stated disjunctively. This account would rely on the assumption that velars and labialized velars are [-high] (cf. Elorrieta Puente 1996) and that the feature [high] is not relevant for labials and alveolars. It would also treat $/ \mathrm{k}^{\mathrm{j}} /$, which conditions raising to [e], as a front velar that is [+high], in keeping with analyses that assume palatalized or front velars share the [+high] feature with palatals (Lahiri \& Blumstein 1984; Odden 2005: 144). The

\footnotetext{
${ }^{5}$ There is one instance of open $/ \varepsilon /$ followed by $/ \mathrm{s}^{\mathrm{j}} /: /$ gut $\varepsilon \mathrm{s} /$ / 'slept'. We consider this to be exceptional. First, there is only one such instance. Second, the / $\varepsilon /$ of this form may come from an original *a, rather than *e, since in other TAM categories, the root has /a/: /r-as $/$ 'sleeps'.

${ }^{6} / \mathrm{w} /$ is also exceptional in the sense that it does not trigger the occurrence of [e] when it precedes a mid-front vowel, as shown in $\S 3.1$.
} 
feature [-labial] eliminates labials, palatalized labials and labialized velars which are [+labial]. Such a proposal has the advantage of capturing the process as raising: the mid-front vowel is raised due to the feature [+high] of the following consonant. Such an analysis can also unify the alternation between [e] and $[\varepsilon]$ on the one hand, and the cooperative raising to [i] on the other, which is clearly a raising process $(\S 4)$, both of which are triggered by the same set of consonants

Issues with such a proposal are the following. First, the assumption that velars are [-high] is problematic; velars are typically treated as [+high] since they are produced with the tongue body raised from a neutral mid-central position (Chomsky \& Halle 1968). In addition, [+high] is what distinguishes velars from their [-high] dorsal counterparts, the uvulars, which are associated with a lower tongue body position. Secondly, [e] and [E] are both considered to be [-high] in standard theories; generally, [e] and $[\varepsilon]$ are distinguished by [tense] or [lax]. Thus, capturing the alternation as a raising assimilatory process is problematic.

An alternative is to characterize the triggering consonants as [+coronal, -anterior, -labial]. Such features, along with those for $/ \mathrm{w} /$ as [-cons, +labial], can capture correctly the environments where [e] is found, without treating velars as [-high]. Moreover, in this analysis, the alternation between the open and closed mid-front vowels no longer requires recourse to the non-standard assumption that the two vowels are distinguished by the feature [high]. However, with such features we cannot capture the insight that the allophony here is likely to be height assimilation triggered by the consonant (even if the feature encoding the assimilation is not [high]). In addition, such an analysis would fail to unify the allophony in question and the cooperative raising of the mid-front vowel to [i], to be discussed in $\S 4$, which is more clearly a raising process.

In historical terms, the environments where [e] is found are those where the second vowel of the disyllabic roots was a high vowel, except for cases where the intervening consonant was bilabial $\left(/ \mathrm{b}^{\mathrm{j}} /, / \mathrm{p}^{\mathrm{j}} /\right)$ or velar $\left(/ \mathrm{k}^{\mathrm{w}} /, / \mathrm{g}^{\mathrm{w}} /\right)$. This can be illustrated by comparing the Teotitlán Zapotec forms to their cognates in Juchitán Zapotec, which preserves the second vowel of disyllabic roots and has raised vowels relative to Teotitlán Zapotec (the Juchitán forms are from Picket et al. 2007). The first three forms in Table 4 have [e] in Teotitlán Zapotec and high vowels in the second syllable in Juchitán Zapotec. On the other hand, the last three forms have $[\varepsilon]$ in Teotitlán Zapotec and [-high] vowels in the second syllable in Juchitán Zapotec.

Table 4. Cognates of forms in Juchitán Zapotec

\begin{tabular}{|c|c|c|}
\hline gloss & Teotitlán & Juchitán \\
\hline 'riverbed' & ge:w & gi:gu \\
\hline 'people' & bēn $:^{j}$ & 'bin:Ǐ \\
\hline 'thorn' & gèts & 'gitfr \\
\hline 'back of' & $\mathrm{d} \varepsilon t \mathrm{~s}$ & 'detfe \\
\hline 'meat' & 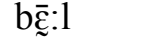 & 'beָ:lă \\
\hline 'tortilla' & get & 'geta \\
\hline
\end{tabular}

The glide /w/, which is the only consonant that is [-high, +labial] and still conditions the occurrence of [e], corresponds to a $/ \mathrm{wu} /$ sequence in Juchitán and/or San Baltazar Chichicapan Zapotec, another Central Zapotec variety that preserves the second syllable of disyllabic roots (the Chichicapan forms are from Thomas Smith-Stark's database):

Table 5. Cognates of forms with final /w/ in Juchitán and Chichicapan Zapotec

\begin{tabular}{|c|c|c|c|}
\hline & Teotitlán & Juchitán & Chichicapan \\
\hline 'coyote' & bě:w & - & 'bwě:wu \\
\hline 'moon' & bẽָ $: w$ & 'bę:wǔ, 'be्త:jǔ & 'bwe'wǔ \\
\hline 'river' & ge:w & 'gi:gu & 'gi:wu \\
\hline
\end{tabular}


Exceptions to the generalization above are very few and include the following. The first such case is where the mid-front vowel is followed by a consonant that should condition the occurrence of [e], but where

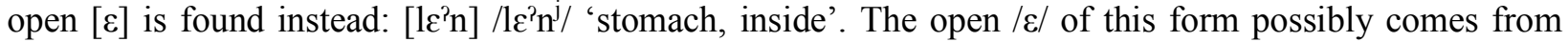
former *a, with subsequent raising due to the following palatalized $/ \mathrm{n}^{\mathrm{j}} /$. In other Central Zapotec varieties, this word has the vowel /a/: San Lucas Quiaviní /lan $n^{\mathrm{j} /}$ and San Pablo Güilá /la? $n^{\mathrm{j}} /$ (López Cruz 1997: 60). The final $/ \mathrm{j} /$ in isolation is not realized, but its underlying presence is justified by its inflected forms: [1 $\left.\varepsilon^{9} n^{\mathrm{j}} \mathrm{a}\right]$ $/ 1 \varepsilon^{i} n^{j}=a /$ 'my stomach'. Another set of exceptions involve those cases where open $[\varepsilon]$ is expected but closed [e] is found instead: [blé:] 'If only!'. Some such cases may be accounted for by another source of closed [e], namely from the sequence /u:j/. Thus, the sequence /u:j/ shows free variation in (18) and (19), while in (20), the form with /u:j/ (with accent) is the numeral 'one'. Its non-tonic counterpart with fused [e] is grammaticalized as an indefinite article:
a. [dǔ:j] 'all (whole)'
b. [dě:]
a. [stú:j] 'another'
b. [sté:]
a. [tu:j] 'one'
b. [te] 'INDEFINITE'

\subsection{Alternations}

The distribution of the mid-front vowels $[\mathrm{e}]$ and $[\varepsilon]$ in Teotitlán Zapotec can further be confirmed by morphologically motivated alternations, where $[\varepsilon]$ in word-final position alternates with $[\mathrm{e}]$ when the following morpheme begins with a consonant that conditions the occurrence of [e].

The first such morpheme is the second person singular enclitic $=w$, the allomorph of $=u$ that appears after a vowel; thus, when this enclitic is attached, the stem final $[\varepsilon]$, as can be observed in the isolated forms in (a), alternates with [e] in (b).

without $=w$

a. $\mathrm{g}^{\mathrm{w}} \varepsilon$ :

$/ g^{\mathrm{w}}-\varepsilon: /$

CMP-go

'went'

(22) a. gule /gu-le $\bar{i} /$

CMP-take.out

'took out'

$$
\begin{aligned}
& \text { with }=w \\
& \text { b. } \mathrm{g}^{\mathrm{w}} \mathrm{e}: \mathrm{w}^{7} \\
& / \mathrm{g}^{\mathrm{w}}-\varepsilon:=\mathrm{u} / \\
& \text { CMP-go=2SG' } \\
& \text { 'you went' }
\end{aligned}
$$

b. gulę̌: $w^{8}$

/gu- $1 \overline{\varepsilon_{i}}=\mathrm{u} /$

CMP-take. out $=2 \mathrm{SG}$,

'you took out' a. $\mathrm{k}^{\mathrm{w}} \varepsilon^{?}$

$/ \mathrm{k}^{\mathrm{w}} \varepsilon^{\mathrm{z}}$

side

'side' b. $k^{\mathrm{w}} \mathrm{e}^{\mathrm{p} w}$

$/ \mathrm{k}^{\mathrm{w}} \varepsilon^{\mathrm{r}}=\mathrm{u} /$

side $=2 \mathrm{SG}$

'your side'

Another morpheme that conditions alternation of word-final $[\varepsilon]$ to [e] is the first person plural enclitics $=(w) u n$ (inclusive) or $=(w) \bar{u} n$ (exclusive). The $/ \mathrm{w} /$ of these enclitics conditions the occurrence of [e], but this $/ \mathrm{w} /$ is deleted due to the general and common in Otomanguean languages (Longacre 1957) OCP-driven phonotactic constraint in Teotitlán Zapotec against the sequence of $/ \mathrm{w} /$ and a back vowel $(/ \mathrm{u} /$ or $/ \mathrm{o} /)$, ${ }^{*} \mathrm{~V}_{[+ \text {backl] }}:^{9}$

\footnotetext{
${ }^{7}$ When the 1SG and 2SG enclitics are attached, the stem modal vowel alternates with a creaky vowel, due to Laryngeal Displacement (Uchihara \& Gutiérrez in press).

${ }^{8}$ Here, the rising tone on the second syllable is due to the combination of the underlying mid tone on the stem, and the high tone which is assigned to the following syllable after a mid tone (tone sandhi). For more detail on tonal processes in Teotitlán Zapotec, see Uchihara \& Gutiérrez (2019).

${ }^{9}$ The 1 PL forms undergo stem alternation, such as prefix alternation, tone alternation and suppletion, in addition to the $[\mathrm{e}] \sim[\varepsilon]$ alternation discussed here (Uchihara \& Gutiérrez in press).
} 
(24)

a. rige:

/ri-ge:/

HAB-fetch

'fetch'

(25)

a. káje?

/káj- $\varepsilon^{2} /$

PROG-drink

'drink'

(26) a. restē:

/r-est $\bar{\varepsilon}: /$

HAB-get.up

'get up' with $=(w) u n$

b. radé:ún

/ra-dé: $=(\mathrm{w}) \mathrm{un} /$

HAB-fetch.1PL=1PL.IN

'we fetch'

b. kádé’un

$/$ ká-d $\tilde{c}^{2}=(\mathrm{w}) \mathrm{un} /$

PROG-drink. $1 \mathrm{PL}=1 \mathrm{PL} . \mathrm{IN}$

'we drink'

b. réstē:ún

$/$ r-éste: $=(\mathrm{w}) \mathrm{un} /$

HAB-get.up.1PL=1PL.IN

'we get up'

The third morpheme that triggers the $[\mathrm{e}] \sim[\varepsilon]$ alternation is the diminutive suffix $\left.-{ }^{2} n \rho\right)$. In isolation, the palatalization is not realized, ${ }^{10}$ but their inflected forms (when followed by a vowel-initial morpheme) justify the presence of the underlying palatalization, as shown in $(27 \mathrm{c}$ and $28 \mathrm{c})$.

\begin{abstract}
without DIM
\end{abstract}
a. ts $\varepsilon^{\text {? }}$

$/$ ts $^{2} /$

voice

'voice of' b. tse?

$/ \operatorname{ts} \varepsilon^{?}-\left({ }^{?}\right) n\left({ }^{j}\right) /$

voice-DIM

'little voice' with DIM + inflection

c. $\operatorname{tse}^{2} n^{\mathrm{j}} \mathrm{u}$

$/ \mathrm{ts} \varepsilon^{2}-\left({ }^{3}\right) \mathrm{n}^{\mathrm{j}}=\mathrm{u} /$

voice-DIM=2SG

'your little voice' a. $\mathrm{d} \varepsilon$

/d $\varepsilon: /$

ash

'ash' b. de?

$/ \mathrm{d} \varepsilon:-{ }^{2} \mathrm{n}\left({ }^{\mathrm{j}}\right) /$

ash-DIM

'little ash' c. $x \operatorname{te}^{3} n^{j} u$

$/ \mathrm{x}-\mathrm{d} \varepsilon:-{ }^{2} \mathrm{n}^{\mathrm{j}}=\mathrm{u} /$

POSS-ash-DIM=2SG

'your little ash'

Lastly, the enclitic $=k^{j}$ 'invisible' also triggers the alternation of the preceding $[\varepsilon]$ to [e]:

$$
\text { without }=k^{j}
$$

a. $\mathrm{r} \bar{\varepsilon}$ :

$/ \mathrm{r} \overline{\mathrm{E}} / /$

DEM.DIST

'there'

$$
\text { with }=k^{j}
$$

b. $\mathrm{rē}^{\mathrm{j}}$

$/ \mathrm{r} \bar{\varepsilon}=\mathrm{k}^{\mathrm{j}} /$

DEM.DIST $=$ INV

'there (invisible)'

\section{The effect of the onset consonant in a closed syllable}

In the previous section, we saw the effect of the postvocalic consonants and /w/ following the mid-front vowel. The allophony of the mid-front vowel is also conditioned by the same subset of consonants (namely, $/ \mathrm{g} /, / \mathrm{d} /, / 3 /$, or $/ \mathrm{J} /, / \mathrm{j} /$, and palatalized consonants) in the prevocalic position, but only when the vowel is in a closed syllable at the same time (\$3.1). This cooperative effect of the consonant height and the syllable structure is further confirmed by alternation evidence (\$3.2).

\footnotetext{
${ }^{10}$ If there was palatalization, it would be clearly audible since the palatalization would be realized as a [j] before [n] in this position, due to $j$-Metathesis (Uchihara \& Gutiérrez in press).

${ }^{11}$ These forms can also be interpreted as containing the 3SG.DEI enclitic =en: 'the voice of a deity', 'the ash of a deity'.
} 


\subsection{Distribution}

First, when the mid-front vowel preceded by one of the conditioning consonants listed in $\S 2$ is in an open syllable, a mid-front vowel $/ \varepsilon /$ is not realized as [e], unlike when they are followed by one of the same consonants, regardless of the phonation type of the vowel.

$\begin{array}{ll}\text { Open syllable } \\ \text { Modal } \\ \mathrm{k}^{\mathrm{j}} \varepsilon: & \text { 'head of' } \\ \mathrm{biz}^{\mathrm{j}} \bar{\varepsilon} & \text { 'water well' } \\ \mathrm{l}^{\mathrm{j}} \varepsilon: & \text { 'Maria' } \\ \mathrm{g}^{\mathrm{j}} \varepsilon: & \text { 'stone' } \\ \mathrm{bis}^{\mathrm{j}} \varepsilon: & \text { 'eagle' } \\ \mathrm{r}-\mathrm{j} \varepsilon: & \text { 'go to origin' } \\ \mathrm{ri}^{\mathrm{j}}-\mathrm{g}^{\mathrm{j}} \varepsilon: & \text { 'squeeze' } \\ \mathrm{ru}^{\mathrm{d}}-\mathrm{d}^{\mathrm{j}} \varepsilon: & \text { 'squeeze' }\end{array}$

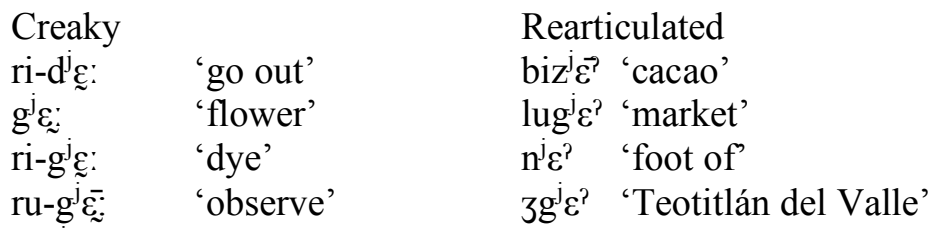

However, when a mid-front vowel preceded by one of these conditioning consonants (but not $/ \mathrm{w} /$ ) is also in a closed syllable, closed [e] is found. The following are examples with coronal consonants $t, d, s, z$, $n$, or $l$ in the postvocalic position:

(31) alveolar plosives ( $\left.t, d_{-}\right)$

$\begin{array}{ll}\text { r-jet } & \text { 'get down' } \\ \text { r-jet } & \text { 'get ground' } \\ \text { r-je:d } & \text { 'get combed' }\end{array}$

(32) alveolar fricatives (_s, z )

ri-t'es 'jumps over'

ri-t'èe:z 'split'

(33) alveolar nasal (_n)

$\mathrm{z}\left({ }^{\mathrm{j}}\right) \overline{\mathrm{e}}: \mathrm{n} \quad$ 'many (countable)'

diě:nd 'store' $(<$ Sp. tienda $)$

otfé:nt 'eighty' $(<$ Sp. ochenta $)$

(34) alveolar lateral ( 1 )

te è:1 'spouse of'

ra-dzē:1 'find'

ri-Se:1 'send'

The mid-front vowel is also realized as [e] after the conditioning consonants when this vowel is also followed by tautosyllabic bilabials $/ \mathrm{p} /$ and $/ \mathrm{b} /(35)$, palatalized labials $/ \mathrm{p}^{\mathrm{j}} /$ and $/ \mathrm{b}^{\mathrm{j}} /(36)$, a velar $/ \mathrm{k} /(37)$ or a labialized velar $/ \mathrm{k}^{\mathrm{w}} /(38)$ in the coda position. The form in (38) shows that a palatalized labial can condition the occurrence of [e] in a closed syllable, even though it does not in the postvocalic position as we have seen in $\S 2$.

(35) labial plosive ( $\mathrm{p}, \mathrm{b})$

$$
\begin{array}{ll}
\mathfrak{t}\left({ }^{\mathrm{j}}\right) \text { ě:p } & \text { 'Josefa' } \\
\text { n'é:b } & \text { 'ice cream' }(<\mathrm{Sp} . \text { nieve })
\end{array}
$$

(36) palatalized labials $\left(p^{\mathrm{j}}, \mathrm{b}^{\mathrm{j}}\right)$

r-(j)ep' 'raise'

káj-ep ${ }^{j} \quad$ 'is going up'

tyěp ${ }^{\mathrm{j}}$ 'will go up 
(37) velar plosive ( $(\mathrm{k})$

$\mathfrak{t}\left({ }^{j}\right)$ é:k 'cheque' $(<$ Sp. cheque $)$

(38) labialized velar $\left(\mathrm{k}^{\mathrm{w}}\right)$

$b^{\mathrm{j} e ̌ k}{ }^{\mathrm{w}}$ 'hawk'

When the mid-front vowel is both preceded and also followed by one of the conditioning consonants in coda position, [e] is found as expected:

\begin{tabular}{|c|c|}
\hline $\int \sqrt{\mathrm{e}}: \mathrm{n}\left({ }^{\mathrm{j}}\right)$ & 'saliva of' \\
\hline nazé:n( $\left(^{j}\right)$ & 'wide' \\
\hline ri- $\int \mathrm{e}^{\mathrm{j}}{ }^{\mathrm{j}}$ & 'untie' \\
\hline ri-zěk ${ }^{j}$ & 'get untied' \\
\hline $\operatorname{bilje}^{?}(\mathrm{j})$ & 'black zapote' \\
\hline gibléé:(j) & 'key' \\
\hline r-unjtee:(j) & 'weave' \\
\hline ru- $\int \overline{\mathrm{e}}: 3$ & 'sneeze' \\
\hline $3 \mathrm{et}^{\mathrm{j}}$ & 'onion' \\
\hline$r-j e t^{j}$ & 'get bent' \\
\hline fté: 3 & 'garlic' \\
\hline r-jety & 'shudder' \\
\hline $\mathrm{g}^{\mathrm{j}} \mathrm{en}:{ }^{\mathrm{j}}$ & 'neck of' \\
\hline$r-j \bar{e}: d^{j}$ & 'get frustrated' \\
\hline ri- $\int \check{e}^{\prime} 1\left(^{j}\right)$ & 'open (it)' \\
\hline$r-j e ̌: 1^{j}$ & 'flourish' \\
\hline ru-tfetf & 'shout' \\
\hline$g^{\mathrm{j}} \mathrm{e} \int^{\mathrm{j}}$ & 'avocado' \\
\hline l'é:(j) & 'lock' \\
\hline tee:(j) & 'correctly' \\
\hline
\end{tabular}

Recall that $/ \mathrm{w} /$ triggers the realization of the preceding mid-front vowel as [e] (§2). However, $/ \mathrm{w} /$ or labialized velars do not condition the occurrence of the following mid-front vowel as [e], even when this vowel is followed by a coda consonant:

$$
\begin{array}{ll}
\mathrm{g}^{\mathrm{w}} \check{\varepsilon} \mathrm{l}: & \text { 'youngest child' } \\
\mathrm{x}^{\mathrm{w}} \check{\varepsilon}: \mathrm{rs} & \text { 'effort' } \\
\mathrm{mw} \varepsilon \dot{\varepsilon}: \mathrm{s} & \text { 'teacher' }(<\text { Sp. maestro })
\end{array}
$$

Thus, the generalization here is that the mid-front vowel is realized as [e] when it is preceded by the conditioning consonants in a closed syllable. This process can be stated informally as follows, where the consonantal feature trigger $(\mathrm{F})$ is unclear (see $\$ 2$ for discussion):

$$
\left./ \varepsilon / \rightarrow[\mathrm{e}] / \mathrm{C}_{\mathrm{F}_{-}} \mathrm{C}\right]_{\sigma}
$$

This is a case of a "cooperative" or "ganging" effect (Flemming 1995; Lionnet 2016, 2017; McPherson 2016) that targets the mid-front vowel: a prevocalic conditioning consonant alone is not 'strong' enough to condition the allophony of the following mid-front vowel, but it does when it 'cooperates' with the syllable structure (closed syllable). One possible phonetic explanation for this effect of the syllable structure is due to undershoot (Lindblom 1990; Moon \& Lindblom 1994) or an imperative to minimize articulatory effort, captured as the constraint LAZY (Kirchner 2004): vowels in a closed syllables tend to be shorter (closed syllable vowel shortening is common cross-linguistically; Maddieson 1985), and shorter vowels fail to reach their lower target positions because speakers do not open their jaws as widely when there are shorter temporal intervals, whether due to speech rate (DiCanio et al. 2015) or lack of prominence (Erickson \& Kawahara 2016). This account assumes that the articulatory position required for $[\varepsilon]$ is farther than that of 
[e] from the baseline or rest position. Recall that in Teotitlán Zapotec both short and long vowels can occur in a closed syllable, as we have seen in \$2.1: there exist near-minimal pairs as in (39) above, ritjes 'jumps over' vs. ritje:z 'split'; however, vowels may be phonetically shorter, whether they are phonemically short or long, in a closed syllable than in an open syllable. ${ }^{12}$ Such an account is all the more plausible since in atonic syllables the realization of the mid-front vowel is [e], as we will see in $\S 5$.

We have seen above that the mid-front vowel preceded by a conditioning consonant has to be in a closed syllable. If the syllable structure really is crucial in predicting the allophony, we would expect $[\varepsilon]$ when the mid-front vowel is followed by a consonant but in a different syllable (that is, $\mathrm{C}_{\mathrm{F}} \varepsilon . \mathrm{CV}$ ). This is in fact true in some cases, as in (42). In (42), both forms are morphologically complex: $r^{j} \varepsilon$ :.dán consists of habitual $r$-, verb root ${ }^{j} \varepsilon$ : 'go to the origin', and the 3PL informal enclitic =dán; $n i s . g^{j} \varepsilon:$. pi: is made up of $n i s$ 'water', $g^{j} \varepsilon$ : 'stone' and bi: 'air'.

$$
\begin{aligned}
& \mathrm{r}^{\mathrm{j}} \varepsilon \text { :.dán (*rje:.dán) 'they go to the origin' } \\
& \text { nis.g }{ }^{\mathrm{j}} \varepsilon \text { :.pi: (*nis.g }
\end{aligned}
$$

However, in other cases, this is not borne out; namely when a closed syllable becomes open due to morpheme concatenation. When a $\mathrm{C}_{\mathrm{F}} \mathrm{eC}$ syllable is followed by a vowel-initial morpheme, thereby rendering the coda consonant heterosyllabic, then the mid-front vowel remains close [e], as can be seen in the following examples. The forms in (b) are without the following morphemes, justifying that the midfront vowel is [e] when there is no following morpheme.

$$
\begin{aligned}
& \text { a. } \mathrm{r}^{\mathrm{j}} \mathrm{e} \cdot \tan \left({ }^{*} \mathrm{r}^{\mathrm{j}} \varepsilon \cdot \tan \right) \\
& / \mathrm{r}-\mathrm{j} \varepsilon \mathrm{t}=\mathrm{an} / \\
& \text { HAB-get.down }=3 \text { SG.INF } \\
& \text { 'he gets down' }
\end{aligned}
$$

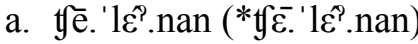

$$
\begin{aligned}
& / \mathrm{t} \overline{\varepsilon_{i}} 1-\varepsilon^{2} \mathrm{n}=\mathrm{an} / \\
& \text { spouse.of-DIM=3SG.INF } \\
& \text { 'his little spouse' }
\end{aligned}
$$

b. $\mathrm{r}^{\mathrm{j}}$ et

/r-jet/

HAB-get.down

b. tẹ: 1

/t $\overline{\varepsilon_{i}}: 1 /$

spouse.of

This lack of allophonic alternation may be due, within a constraint-based paradigm, to Paradigm Uniformity (Steriade 1999; Raffelsiefen 2005, among others): the allophone [e] is maintained even when the syllable structure changes due to morpheme concatenation, in order to maintain the stem form (in this case, the nucleus vowel) invariable.

So far, we have not found any exceptions to the generalization above. There are some apparent exceptions where a closed [e] is found after one of the conditioning consonants in an open syllable, but in all of such cases the mid-front vowel can optionally be followed by a palatal glide $j$, which conditions the raising of the preceding mid-front vowel, as we saw in $\S 2$.

$$
\begin{aligned}
& \text { Apparent exceptions } \\
& \text { l'é:(j) 'lock' } \\
& \text { tè:(j) 'correctly' }
\end{aligned}
$$

\subsection{Alternations}

Alternations between closed $[\mathrm{e}]$ and open $[\varepsilon]$ in the same morpheme, according to the preceding consonant and the syllable structure, are also found. Thus, the following forms, both in a closed syllable, are in free

\footnotetext{
12 The interaction of syllable structure and vowel quality is found in English, where lax vowels are found only in tonic closed syllables. It has been argued that this is because lax vowels are monomoraic and thus need a consonant in the coda position to satisfy Weight-to-Stress principle (Prince 1990), while tense vowels are bimoraic (Hammond 1997). However, the situation in Teotitlán Zapotec is the opposite: $[\varepsilon]$ is found both in open and closed syllables while $[\mathrm{e}]$ is only found in closed syllables.
} 
variation, with the $[\mathrm{e}] \sim[\varepsilon]$ alternation conditioned by the presence or absence of preceding palatalization. This alternation confirms the importance of the feature of the prevocalic consonant.
not preceded by $\mathrm{j}$
preceded by $\mathrm{j}$
a. [ritē:z] 'split'
b. $\left[\mathrm{rit}^{\dagger} \overline{\mathrm{e}}: \mathrm{z}\right]$
a. [rites] 'jump over'
b. $\left[\right.$ rit $\left.^{\mathrm{j}} \mathrm{es}\right]$

In the following cases, when a stem with open $[\varepsilon]$ is followed by a palatalized labial (which itself does not condition raising in the postvocalic position; §2) and is preceded by a morpheme ending in one of the conditioning consonants, this mid-front vowel is realized as a closed [e]. This again confirms the role of the prevocalic consonant in the allophony. Note here that the Paradigm Uniformity is not maintained and rather the stem vowel alternates between $[\varepsilon]$ and $[\mathrm{e}]$.

$$
\text { not preceded by } \mathrm{C}_{\mathrm{F}}
$$

a. $r \varepsilon p^{j}$

$/ \mathrm{r}-\varepsilon \mathrm{p}^{\mathrm{j} /}$

HAB-go.up

'go up'

(49) preceded by $\mathrm{C}_{\mathrm{F}}$

b. kájep ${ }^{j}$

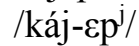

PROG-go.up

'is going up'

b. tgěp ${ }^{j}$

$/ \mathfrak{t}-\check{\varepsilon p}^{\mathrm{j}} /$

POT-go.up

'will go up'

When a stem with an open-mid $[\varepsilon]$ is in an open syllable, this vowel does not alternate with the closedmid [e] as in the cases above. This confirms the importance of the syllable structure (closed syllable) in the allophony. In (50), the (b) form has the progressive prefix, which ends in $/ \mathrm{j} /$; however, this $/ \mathrm{j} /$ does not condition the allophony of the root-final vowel.
not preceded by $j$
preceded by $j$
a. $r \varepsilon^{?}$
$/ \mathrm{r}-\varepsilon^{2} /$
HAB-drink
'drink'
b. káje? (*káje?)
$/$ káj- $\varepsilon^{2} /$
PROG-drink
'is drinking'

\section{Cooperative raising to [i]}

In the previous subsection, we saw that a subset of prevocalic consonants $(/ \mathrm{j} /, / \mathrm{J} /, / \mathrm{z} /, / \mathrm{g} /, / \mathrm{d} / \mathrm{J} /$, or palatalized consonants) and the syllable structure (a closed syllable) team up to raise a mid-front vowel. When the postvocalic coda consonant is also one of the conditioning consonants (including $/ \mathrm{w} /$ ), the mid-front vowel can raise to [i], neutralizing with the underlying /i/ (with a subsequent deletion of the preceding $/ \mathrm{j}$ / or palatalization, due to the general OCP-driven constraint that prohibits the sequence $* j i$ ).

Such an alternation can be observed with the $2 \mathrm{SG}$ enclitic $=w$. The (a) forms are isolation forms with open $/ \varepsilon /$, while (b) forms are followed by $=w$ and have $/ \mathrm{i} /$ instead of $/ \varepsilon /$.
a. $n^{\mathrm{j}} \varepsilon^{?}$
$/ \mathrm{n}^{\mathrm{j}} \varepsilon^{\mathrm{i}} /$
foot
'foot'

without $=w$

a. $\mathrm{k}^{\mathrm{j}} \varepsilon$ :

$/ \mathrm{k}^{\mathrm{j}} \varepsilon$ :/

head

'head'

$$
\begin{aligned}
& \text { with }=w \\
& \text { b. } \operatorname{ni}^{?} \mathrm{w}\left({ }^{\mathrm{j}} \mathrm{n}^{\mathrm{j}} \mathrm{e}^{\mathrm{p} w}\right) \\
& / \mathrm{n}^{\mathrm{j}} \varepsilon^{\mathrm{c}}=\mathrm{u} / \\
& \text { foot=2SG } \\
& \text { 'your foot' }
\end{aligned}
$$

b. ki:w

$/ \mathrm{k}^{\mathrm{j}} \varepsilon:=\mathrm{u} /$

head $=2 \mathrm{SG}$

'your head' 
(53)

a. $\operatorname{tg}^{\prime}$

$/ \mathrm{t}-\varepsilon: /$

POT-go

'will go'

(54)
a. $\operatorname{rid}^{\mathrm{j}} \varepsilon$ :
/ri-d $\mathrm{d}^{\mathrm{j}}: /$
HAB-leave
'leave'
b. t⿳⺈: $:$ w $(*$ teề:w $)$
$/ \mathrm{t}-\varepsilon:=\mathrm{u} /$
POT-go $=2 \mathrm{SG}$
'you will go'
b. ridi:w
$/ \mathrm{ri}-\mathrm{d}^{\mathrm{j}} \varepsilon:=\mathrm{u} /$
HAB-leave $=2 \mathrm{SG}$
'you leave'

This cooperative effect appears to be at work only in derived contexts. Thus, lexical sequences of $\mathrm{C}_{\mathrm{F}} \mathrm{C}_{\mathrm{F}}$ are attested, as we saw in $\S 3.1$, which should not be attested if this cooperative effective were operative at the lexical level. Below are repeated examples from (39):

\begin{tabular}{|c|c|}
\hline $\int \overline{\mathrm{e}}: n\left({ }^{\mathrm{j}}\right)$ & 'saliva of' \\
\hline nazé:n(j) & 'wide' \\
\hline 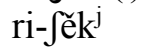 & 'untie' \\
\hline ri-zěk ${ }^{\mathrm{j}}$ & 'get untied' \\
\hline $\operatorname{bilje} \bar{e}^{?}(\mathrm{j})$ & 'black zapote' \\
\hline 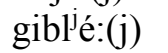 & 'key' \\
\hline r-unjte:(j) & 'weave' \\
\hline ru- $-\sqrt{\mathrm{e}}: 3$ & 'sneeze' \\
\hline $3 \mathrm{et}^{\mathrm{j}}$ & 'onion' \\
\hline$r-j e t^{j}$ & 'get bent' \\
\hline $\int t^{j} e^{\prime}: 3$ & 'garlic' \\
\hline r-jetf & 'shudder' \\
\hline $\mathrm{g}^{\mathrm{j}} \mathrm{en}^{\mathrm{j}}$ & 'neck of' \\
\hline$r-j \bar{e}: d^{j}$ & 'get frustrated' \\
\hline ri- $\int \mathrm{e}^{\prime} 1\left({ }^{j}\right)$ & 'open (it)' \\
\hline$r-j e ̌ e: 1^{j}$ & 'flourish' \\
\hline ru-tfetf & 'shout' \\
\hline $\mathrm{g}^{\mathrm{j}} \mathrm{e} \int^{\mathrm{s}}$ & 'avocado' \\
\hline l'é:(j) & 'lock' \\
\hline țed:(j) & 'correctly' \\
\hline
\end{tabular}

On the other hand, several cases of lexical $\mathrm{C}_{\mathrm{F}} \mathrm{C}_{\mathrm{F}}$ sequences are also attested, which could have historically come from *e surrounded by the conditioning consonants, and then raised to /i/ due to this cooperative effect; in fact, $r i$-zitf 'get angry' has *e in Kaufman's (2016) reconstruction (*tze:7tzE):

\begin{tabular}{|c|c|}
\hline 3în:ds & 'pineapple' \\
\hline $\int \mathrm{i}: 1^{j}$ & 'wing of' \\
\hline $3 i_{1}^{i}: 1^{\mathrm{j}}$ & 'sheep' \\
\hline $\int_{1}^{1}: 3$ & 'chepil' \\
\hline $\mathrm{gu} \int \mathrm{in}:{ }^{\mathrm{j}}$ & 'night' \\
\hline $\mathrm{gik}^{\mathrm{j}}$ & 'once upon a time' \\
\hline ru- jin $^{j}$ & 'defecate' \\
\hline ri-zît $d$ & 'get angry' \\
\hline ru-ty & 'make (someone) angry' \\
\hline
\end{tabular}

The cooperative effect is also not observed with the suffixation of the diminutive (which has a palatalized coda), even when the root is preceded by one of the conditioning consonants. Thus, in the (b) forms in the following examples, the open $/ \varepsilon /$ of the stem does not alternate with $/ \mathrm{i} /$ even though this vowel is preceded by $/ \mathrm{j} /$ and followed by the palatalized consonant of the diminutive: 
(57)

a. bik ${ }^{\mathrm{j}} \hat{\varepsilon}:$

/bik $\hat{\mathrm{k}} \mathrm{\hat { \varepsilon }}: /$

nit

'nit'

(58) b. bik $\hat{\mathrm{e}}^{\mathrm{T}} \mathrm{n}\left({ }^{*}\right.$ bikî?n$)$

/bik ${ }^{\mathrm{j}} \hat{\tilde{E}}:{ }^{?} n^{\mathrm{j}} /$

nit-DIM

'little nit'

b. $\int k^{j} \hat{e ̂}^{\gamma} n^{j} a$

$/ \int-g^{j} \hat{\varepsilon}:-n^{j}=a /$

POSS-stone-DIM=1SG

'my little stone'

This cooperative raising discussed in this section can be formulated as follows. Again, see $\$ 2.1$ for the characterization of the feature $\mathrm{F}$ associated with consonants adjacent to the vowel.

$$
\begin{aligned}
& \text { Cooperative raising to }[\mathrm{i}] \\
& / \varepsilon / \rightarrow[\mathrm{e}] \sim[\mathrm{i}] / \mathrm{C}_{\mathrm{F}}\left\{\mathrm{C}_{\mathrm{F}}, / \mathrm{W} /\right\}
\end{aligned}
$$

\section{Neutralization in atonic positions}

Another factor that conditions the $[\mathrm{e}] \sim[\varepsilon]$ alternation in Teotitlán Zapotec is accent: in atonic positions, especially in a closed syllable, we find the allophone [e].

In Teotitlán Zapotec, accent is culminative and obligatory; there is only one accent per phonological word (Picket 1951; Mock 2010: 202; Pérez Báez et al. 2015). The accent falls on the last syllable of the phonological word, which consists of a root (60) plus an optional prefix (61) or suffix (62), or of a compounded root (63). In the following examples, the position of the accent is represented with the IPA symbol for primary stress [' $]$ before the tonic syllable, and the phonological word is circumscribed in parentheses

$(60)$

$$
\begin{aligned}
& \text { a. (ri'za:) } \\
& \text { /ri-za:/ } \\
& \text { HAB-walk } \\
& \text { 'walks' }
\end{aligned}
$$

(62)

$$
\begin{aligned}
& \text { a. (gú' } \left.n \varepsilon^{2} n\right) \\
& \text { /gû? } n-\varepsilon^{3} n / \\
& \text { bull-DIM } \\
& \text { 'little bull' }
\end{aligned}
$$

$$
\begin{aligned}
& \text { a. (bedj'ngu:1) } \\
& \text { /bs:dj-ngu:1/ } \\
& \text { chicken-male } \\
& \text { 'turkey' }
\end{aligned}
$$
b. ('ju:) 'ground'

b. (gu'ri:)

/gu-ri:/

CMP-sit.down

'sat down'

b. (gubá'ni’n)

/gubâ'nj-i'n/

broom-DIM

'little broom'

$$
\begin{aligned}
& \text { b. (diz'za:) } \\
& \text { /did:dz-za:/ } \\
& \text { word-Zapotec } \\
& \text { 'Zapotec language' }
\end{aligned}
$$

Since Teotitlán Zapotec is tonal, pitch is not a reliable acoustic correlate of accent. It has been proposed that the accent correlates more reliably with vowel duration (Picket 1951; Picket et al. 2001: 16; ChávezPeón 2008; Mock 2010: 202). It could be the case that the most reliable acoustic correlate of accent is intensity (as claimed for one Central Valley Zapotec variety, San Lucas Quiaviní Zapotec; Chávez-Peón 2008). The full range of phonological contrasts is expressed within tonic syllables and is often neutralized in atonic syllables (Smith-Stark 2003: 25, 32; Chávez Peón 2015), which is cross-linguistically common (Gordon 2011): vowel duration (a contrast that is itself marginal), phonation and tonal contrasts are also neutralized in atonic positions. 
In this section, we will first look at the neutralization of the mid-front vowel in atonic positions, especially in a closed syllable ( $\$ 5.1)$; a cooperative effect between the consonant height and accent is also observed (\$5.2).

\subsection{Neutralization to [e] in atonic positions}

In general, the closed-mid [e] is found in an atonic position. First, only [e], and not $[\varepsilon]$, is found in proclitics and enclitics, which lack accent.
(64) Enclitics:
$=\bar{e}$ 'INANIMATE', =en 'DEITIC', =ēn 'FOCUS'
(65) Proclitics:

$$
\mathrm{ke \overline {d }}=\text { 'NEG', te= 'INDEFINITE', té= 'SUBORDINATOR' }
$$

Alternations between $[\mathrm{e}]$ and $[\varepsilon]$ due to accent are also common. Thus, the andative and venitive

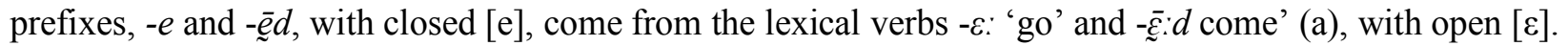
When they function as prefixes, they lose accent and concomitantly open $[\varepsilon]$ alternates with closed [e] (along with a shortening of the vowel), as in (b):
a. $r \varepsilon:$
$/ \mathrm{r}-\varepsilon: /$
HAB-go
'go'

(67)
b. re'kā'n
$/ \mathrm{r}-\varepsilon-\mathrm{k} \overline{\mathrm{a}}^{\mathrm{P}}=(\overline{\mathrm{a}}) \mathrm{n} /$
HAB-AND-get $=3$ SG.F
'he goes to get'
b. rēd'tá:w
/r-ęd-'tá:w/
HAB-VEN-eat
'come to eat'

Another case of alternation can be observed with the suffixation of the comitative $-n \bar{\varepsilon}$. When a suffix is attached to the base, the suffix is incorporated into the phonological word along with the base and accent is assigned to the final syllable of the phonological word (the syllable of the suffix). The verb base /-us\&: $\mathrm{d} /$ thus loses its accent and concomitantly open $/ \varepsilon /$ optionally alternates with closed [e], along with neutralization of the creaky vowel with the modal vowel.
a. ru'se:d
/r-use:d/

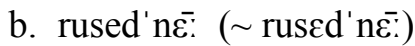
HAB-study
'study'
/r-use:d-ne://
HAB-study-COM
'study with'

On the other hand, the $[\varepsilon] \sim[\mathrm{e}]$ alternation is not observed with the suffixation of the diminutive, which also causes a shift in the position of accent. In (69), the root /bel:/ 'fish' retains its open-mid-front vowel despite the loss of accent due to the suffixation of the diminutive.
a. bel:
/bel:/
fish
b. be' $1: \varepsilon^{?} n \quad\left(*\right.$ be' $\left.1: \varepsilon^{?} n\right)$
$/ \mathrm{b} \varepsilon^{\prime} 1:-\varepsilon^{2} \mathrm{n} /$
fish-DIM
'fish'
'little fish'

The difference between the comitative suffix in (68) above and the diminutive in (69) could be due to the difference in the syllable structure, as we have seen in $\S 3$. Since the comitative suffix begins with a consonant, it does not affect the syllabification of the stem syllable; if the stem syllable is closed, it remains closed, ${ }^{13}$ and since a vowel in a closed syllable has a shorter duration than in an open syllable (Maddieson

\footnotetext{
${ }^{13} \mathrm{We}$ only have one vowel-final stem with the comitative suffix, $r-e-n \varepsilon$ : 'take'. Here, the stem in isolation is $-\varepsilon$ : 'go' and thus undergoes raising even though this vowel is in an open syllable. However, this suffixed form is highly lexicalized and the raising of the mid-front vowel in this case could be due to this lexicalization.
} 
1985), the mid-front vowel fails to achieve its lower target of [ $\varepsilon]$ due to undershoot (Lindblom 1990; Moon \& Lindblom 1994). On the other hand, the diminutive suffix is vowel-initial, and thus if the preceding stem ends in a consonant, as in (69b), ${ }^{14}$ the syllable structure is modified and now the mid-front vowel is in an open syllable, which affords the necessary time for the mid-front vowel to be realized as the lower allophone $[\varepsilon]$.

The $[\varepsilon] \sim[\mathrm{e}]$ alternation due to accent can also be observed in some compounds. In compounds, more than one root constitutes a single phonological word and all roots, except for the final one, lose accent. Concomitantly, open $[\varepsilon]$ alternates with closed $[\mathrm{e}]$ in atonic syllables, as in the following examples. The forms in (a) justify the vowel $[\varepsilon]$ in isolation.
a. get
/get/
tortilla
'tortilla'
(71) a. riz๕: $\mathrm{b}^{\mathrm{j}}$
$/ r i-z \varepsilon: b^{j} /$
HAB-get.hanged
'is hanged'
b. get' guي̣:: $(\sim$ get' gụ̆: $)$
/get+gù $: /$
tortilla+?
'tamal'
b. rizeb'la:z ( rizeb'la:z)
/ri-z\&: $b^{\mathrm{j}}+\mathrm{la}_{\mathrm{i}} \mathrm{z} /$
HAB-get.hanged+essence
'yearn'

However, the alternation is not observed in many cases of compounds. Thus, in the following compounded forms, even though the first member of the compound loses accent, it keeps its open-mid vowel $[\varepsilon]$ :

$$
\begin{aligned}
& \text { re } \varepsilon^{\text {'re:n }} \\
& / \mathrm{r}-\varepsilon^{\mathrm{P}}+\mathrm{re}: \mathrm{n}\left({ }^{\mathrm{j}}\right) / \\
& \text { HAB-drink+blood } \\
& \text { 'cause evil eye' } \\
& \mathrm{g}^{\mathrm{j}} \varepsilon^{\prime} \text { lats } \\
& / \mathrm{g}^{\mathrm{j}} \boldsymbol{\varepsilon}+\text { lats/ } \\
& \text { stone }+ \text { field } \\
& \text { 'Ocotlán' }
\end{aligned}
$$

Here again, the difference between the cases where the mid-front vowel undergoes alternation as in (70) and (71) on the one hand, and where it does not as in (72) and (73) on the other, could be the syllable structure: in the former case the mid-front vowel in an atonic syllable is in a closed syllable, while in the latter it is in an open syllable. Thus, we may want to generalize that the realization of the mid-front vowel as [e] is only observed in an atonic syllable when this syllable is closed. However, a closed-mid [e] is also found in an open atonic syllable, as we have already seen: the proclitics $t e=$ 'indefinite' and $t e ́=$ 'subordinator', and the andative prefix $e$ - which comes from the verb - $\varepsilon$ : 'go'. Thus, even though there is a strong preference for [e] in an atonic position to occur in a closed syllable, this is not absolute.

We now return to the puzzle of the mid-front vowel neutralizing to the conditioned allophone [e], rather than $[\varepsilon]$. As we saw in the preceding subsections, open $[\varepsilon]$ is the regular historical reflex of proto *e, and this fact is also reflected in the synchronic phonology. First, $[\varepsilon]$ occurs in fewer restricted segmental environments than [e], which is the conditioned allophone. Secondly, $[\varepsilon]$ is more common than [e] in tonic syllables, as we saw above. In an atonic position, however, the mid-front vowel is realized as [e]. Here again, the raising in an atonic position may be due to articulatory undershoot (Lindblom 1990; Moon \& Lindblom 1994). In $\S 3.1$, we argued that the realization as [e] in a closed syllable preceded by one of the

\footnotetext{
${ }^{14}$ When the stem is vowel-final, the diminutive suffix fuses with the stem and thus the suffixed form becomes a closed syllable. In this case, the mid-front vowel in the stem is raised to [e] since the final consonant of the diminutive suffix is underlyingly palatalized, as we saw in $\S 4.2: d \varepsilon$ : 'ash', $d e^{2} n($ ) 'little ash'.
} 
conditioning consonants is due to undershoot; a vowel duration is shorter in a closed syllable and thus the jaw is not opened wide enough as in an open syllable. The same line of explanation could be valid for "raising" or "tensing" in an atonic position: atonic syllables have less prominence and thus less jaw movement (Erickson \& Kawahara 2016), and therefore the vowel is realized as [e].

Another alternative explanation for the raising effect in an atonic position is contrast enhancing reduction (Crosswhite 2001, 2004; Gordon 2011): vowels in atonic positions become more peripheral (raising in the cases of $/ \mathrm{e} / \rightarrow[\mathrm{i}]$ and $/ \mathrm{o} / \rightarrow[\mathrm{u}]$ and lowering in the cases of $/ \mathrm{e} /, / \mathrm{o} / \rightarrow[\mathrm{a}]$ ). This maximizes the perception of the contrast in atonic contexts, where these vowels are perceptively more vulnerable, since peripheral vowels $/ \mathrm{i} /, / \mathrm{u} / \mathrm{and} / \mathrm{a} / \mathrm{have}$ special status. Thus, reduction by tensing $(/ \varepsilon / \rightarrow[\mathrm{e}], / \mathrm{J} / \rightarrow[\mathrm{o}])$ is cross-linguistically more common than the change in the opposite direction (Crosswhite 2004: 14) and is exactly what happens in Teotitlán Zapotec.

\subsection{Cooperation of accent and consonant height}

In $\S 3$ and $\S 4$, we saw the cooperative effect between the prevocalic consonant and the syllable structure in the allophonic alternation of the mid-front vowel. Another case of the cooperative effect is found when [e] is preceded by one of the conditioning consonants and in an atonic position, especially in a closed syllable. Thus, the $[\mathrm{e}]$ of the deictic pronominal enclitic $=e n$, the inanimate pronominal enclitic $=\bar{e} n$, or the focus enclitic $=\bar{e} n$ alternates with a high-front vowel [i] after one of the conditioning consonants.

(74)

(75)
/bé: $\mathrm{d}=\overline{\mathrm{e}} \mathrm{n} /$
Pedro $=$ FOC
'(it is) Pedro'
a. bé:dēn
a. $\mathrm{r}^{\mathrm{j}} \mathrm{a}: \mathrm{b} \overline{\mathrm{n}}$
$/ r-j a: b=\bar{e} n /$
HAB-fall $=$ INAN
'it falls'
b. $x^{w}$ á:nīn
/ ${ }^{w}{ }^{w}: n^{j}=\bar{e} n /$
Juan=FOC
'(it is) Juan'
b. rā:līn
HAB-be.born $=$ INAN
$/ \mathrm{r}-\overline{\mathrm{a}}: \mathrm{l}^{\mathrm{j}}=\overline{\mathrm{e}} \mathrm{n} /$
'it is born'

This alternation is limited to certain cases. Thus, in the following cases, the sequence of a conditioning consonant and a mid-front vowel does not yield a high front vowel in an atonic syllable of compounds (i.e., all syllables except for the last one). Here the syllable structure does not seem to be a conditioning factor, since neither is raising to [i] observed in a closed syllable, as shown in (76).

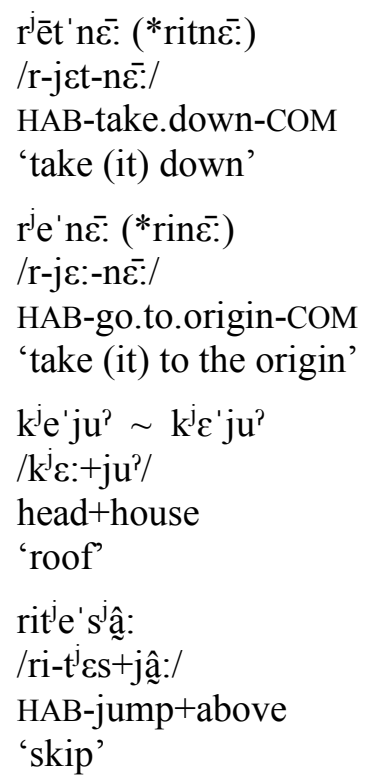




\section{Summary}

This paper has examined the complex phonological factors conditioning the allophony of the mid-front vowel in Teotitlán Zapotec. Even though speakers are well aware of the contrast, the distribution of [e] and $[\varepsilon]$ is mostly predictable, which calls into question the phonemic, contrastive status of these vowels. Open $[\varepsilon]$ is the regular reflex of the Proto-Zapotec ${ }^{*} \mathrm{e}$ and the distribution of [e] is more limited than that of $[\varepsilon]$. In a tonic syllable, [e] is found before a subset of consonants $((/ \mathrm{j} /, / \mathrm{g} /, / \mathrm{d} / /, / \mathrm{J} /, / 3 /$ or palatalized consonants), represented as $\mathrm{C}_{\mathrm{F}}$ throughout the paper, or $/ \mathrm{w} /(\S 2)$. When the mid-front vowel is preceded by one of these consonants, $[\mathrm{e}]$ is found when this vowel is in a closed syllable $(\S 3)$. When the mid-front vowel is preceded and followed by these consonants, the vowel can be raised further to a high-front vowel [i] in certain contexts $(\S 4)$. In other contexts in a tonic syllable, $[\varepsilon]$ is found. In an atonic syllable, the mid-front vowel is usually realized as [e], especially in a closed syllable, and when it is also preceded by one of the conditioning consonants, it may further raise to [i] (\$5). Table 6 summarizes the distribution of [e] and $[\varepsilon]$, in addition to [i], according to the accent, preceding consonant, syllable structure and the features of the consonants in the coda position

Table 6: Distribution of [e] and [ع] (as well as [i]) in Teotitlán Zapotec

\begin{tabular}{|c|c|c|c|c|}
\hline accent & Preceding $\mathrm{C}$ & syllable & Following $\mathrm{C}$ & $\mid \varepsilon /$ \\
\hline \multirow{5}{*}{ tonic } & \multirow[t]{3}{*}{$/ \mathrm{C}_{\mathrm{F}}$} & \multirow[t]{2}{*}{ closed } & $/ \mathrm{C}_{\mathrm{F}}$ and $/ \mathrm{w} /$ & {$[\mathrm{i}],[\mathrm{e}]$} \\
\hline & & & 1 & [e] \\
\hline & & open & & {$[\varepsilon]$} \\
\hline & \multirow[t]{2}{*}{ /elsewhere } & & / $\mathrm{C}_{\mathrm{F}}$ and $/ \mathrm{W} /$ & [e] \\
\hline & & & /_elsewhere & {$[\varepsilon]$} \\
\hline \multirow[t]{3}{*}{ atonic } & $/ \mathrm{C}_{\mathrm{F}}$ & & any & [i], [e] \\
\hline & \multirow[t]{2}{*}{ /elsewhere } & closed & & [e] \\
\hline & & open & & {$[\mathrm{e}],[\varepsilon]$} \\
\hline
\end{tabular}

The distribution of the allophones [e] and $[\varepsilon]$ in Teotitlán Zapotec is mostly predictable from phonological factors and thus their distribution is complementary, but these factors are complex, involving the features of the adjacent consonants, syllable structure and accent. It could be the case that the fact that the difference between $[\mathrm{e}]$ and $[\varepsilon]$ is salient for the speakers, despite their complementary distribution, is attributed to these complex phonological factors; it could be the case that memorizing each morpheme with either $[\mathrm{e}]$ and $[\varepsilon]$ specified is no less 'economical' than acquiring all these complex phonological factors. A cross-linguistic study of allophony of complex distributions like the one governing $[\mathrm{e}]$ and $[\varepsilon]$ in Teotitlán Zapotec would confirm if this is the case or not.

\section{References}

Arellanes, Francisco. 2009. El sistema fonológico y las propiedades fonéticas del Zapoteco de San Pablo Güilá. Ciudad de México: El Colegio de México dissertation.

Arellanes, Francisco, Mario Chávez Peón, Adela Covarrubias, Mario Hernández, Miriam Manzano, Sofia Morales, Rosa María Rojas, Carolos Wagner \& Victoria Zárate. 2017. Hacia una dialectología de base fónica en el zapoteco del valle: el caso de la sexta vocal [i]. In Leonor Orozco \& Alanso Guerrero (eds.), Cambio y variación lingüística: estudios de variación geolingüística, 365-398. Ciudad de México: Instituto Nacional de Antropología e Historia.

Beam de Azcona, Rosemary, Francisco Arellanes Arellanes, Mario Chávez Peón, Mario Hernández Luna, Sofía Gabriela Morales Camacho, Carlos de Jesús Wagner Oviedo \& Miriam Itzel Manzano Corona. 2019. Umlaut (armonía vocálica) en el desarrollo histórico de las lenguas zapotecas. In Lucero Meléndez \& Marcela San Giacomo (eds.), Debates en torno a la lingüística histórica indomexicana. Ciudad de México: IIA-UNAM. 
Boomershine, Amanda, Kathleen Currie Hall, Elizabeth Hume \& Keith Johnson. 2008. The impact of allophony versus contrast on speech perception. In Peter Avery, Elan Dresher \& Keren Rice (eds.), Contrast in phonology, 146-172. Berlin: Mouton de Gruyter.

Chávez-Peón, Mario E. 2010. The interaction of metrical structure, tone and phonation types in Quiavini Zapotec. Vancouver, BC: The University of British Columbia dissertation.

Chomsky, Noam \& Morris Halle. 1968. The Sound pattern of English. New York: Harper \& Row.

Crosswhite, Katherine. 2001. Vowel reduction in Optimality Theory. New York: Routledge.

Crosswhite, Katherine. 2004. Vowel reduction. In Bruce Hayes, Robert Kirchner \& Donca Steriade (eds.), Phonetically based phonology, 191-231. New York: Cambridge University Press.

DiCanio, Christian, Hosung Nam, Jonathan D. Amith, Rey Castillo García \& Douglas H. Whalen. 2015. Vowel variability in elicited versus spontaneous speech: Evidence from Mixtec. Journal of Phonetics 48. 45-59. https://doi.org/10.1016/j.wocn.2014.10.003.

Elorietta Puente, Francisco Javier. 1996. A bipolar model of height in vowels and consonants. Austin, TX: The University of Texas at Austin dissertation.

Erickson, Donna \& Shigeto Kawahara. 2016. Articulatory correlates of metrical structure: Studying jaw displacement patterns. Linguistic Vanguard 2. 103-118. https://doi.org/10.1515/lingvan-2015-0025.

Flemming, Edward. 1995. Auditory representations in phonology. Los Angeles, CA: University of California, Los Angeles dissertation.

Gordon, Matthew. 2011. Stress: Phonotactic and phonetic evidence. In Marc van Oostendorp, Colin J. Ewen, Elizabeth Hume \& Keren Rice (eds.), The Blackwell companion to phonology, 924-948. Oxford: Wiley-Blackwell.

Hall, T.A. 2007. Segmental features. In Paul de Lacy (ed.), The Cambridge handbook of phonology, 311334. Cambridge: Cambridge University Press.

Hall, Kathleen Currie. 2013. A typology of intermediate phonological relationships. The Linguistic Review 30(2). 215-275. https://doi.org/10.1515/tlr-2013-0008.

Hammond, Michael. 1997. Vowel quality and syllabification in English. Language 73(1). 1-17. https://www.jstor.org/stable/416591.

Hayes, Bruce. 2009. Introductory phonology. Oxford: Wiley-Blackwell.

Hume, Elizabeth. 1992. Front vowels, coronal consonants and their interaction in non-linear phonology. Ithaca, NY: Cornell University dissertation.

INEGI (Instituto Nacional de Estadística y Geografía). 2000. XII Censo general de población y Vivienda. Retrived on Oct $28^{\text {th }}, 2019$. http://www.cdi.gob.mx/indicadores/em_cuadro01_oax.pdf

Jaeger, Jeri. 1983. The fortis/lenis question: Evidence from Zapotec and Jawoñ. Journal of Phonetics 11. $177-89$.

Kaufman, Terrence. 2015. A typologically odd phonological reconstruction for Proto-Sapotekan: Stemfinal *k. Albany, NY: PDLMA Publications.

Kaufman, Terrence. 2016. Proto-Sapotek(an) reconstructions. Albany, NY: PDLMA Publications.

Kirchner, Robert. 2004. Consonant lenition. In Bruce Hayes Robert Kirchner \& Donca Steriade (eds.), Phonetically based phonology, 313-345. Cambridge: Cambridge University Press.

Lahiri, Aditi \& Sheila E. Blumstein. 1984. A re-evaluation of the feature "coronal". Journal of Phonetics 12. 133-145. https://doi.org/10.1016/S0095-4470(19)30860-5.

Lindblom, Björn. 1990. Explaining phonetic variation: A sketch of the h\&h theory. In Hardcastle, William J. \& Alain Marchal (eds.), Speech production and speech modelling, 403-439. Boston, MA: Kluwer Academic Publishers.

Lionnet, Florian. 2016. Subphonemic teamwork: A typology and theory of cumulative coarticulatory effects in phonology. Berkeley, CA: University of California dissertation.

Lionnet, Florian. 2017. A theory of subfeatural representations: The case of rounding harmony in Laal. Phonology 34. 523-564. https://doi.org/10.1017/S0952675717000276.

Longacre, Robert E. 1957. Proto-Mixtecan. International Journal of American Linguistics 23(4). 1-195. 
López Cruz, Ausencia. 1997. Morfología verbal del zapoteco de San Pablo Güilá. Ciudad de México: Escuela Nacional de Antropología e Historia bachelor's thesis.

Maddieson, Ian. 1985. Phonetic cues to syllabification. In Victoria Fromkin (ed.), Phonetic linguistics: Essays in honor of Peter Ladefoged, 203-221. New York: Academic Press.

McPherson, Laura. 2016. Cumulativity and ganging in the tonology of Awa suffixes. Language 92(1). 3866. https://doi.org/10.1353/lan.2016.0010.

Merrill, Elizabeth D. 2008. Tilquiapan Zapotec. Journal of the International Phonetic Association 38(1). 107-114. https://doi.org/10.1017/S0025100308003344.

Mock, Carol. 2010. Pitch accent and stress in Isthmus Zapotec. In Harry van der Hülst \& Norval Smith (eds.), Autosegmental studies on pitch accent, 197-224. Berlin, Boston: De Gruyter Mouton.

Moon, S.-J. \& Björn Lindblom. 1994. Interaction between duration, context, and speaking style in English stressed vowels. Journal of the Acoustical Society of America 96(1). 40-55. https://doi.org/10.1121/1.410492.

Munro, Pamela, Felipe H. Lopez, Olivia V. Méndez [Martínez], Rodrigo Garcia \& Michael R. Galant. 1999. Di'csyonaary X:tèe'n Dii'zh Sah Sann Lu'uc (San Lucas Quiavini Zapotec Dictionary/Diccionario Zapoteco de San Lucas Quiavini). Los Angeles: (UCLA) Chicano Studies Research Center Publications.

Nellis, Donald G. \& Barbara E. Hollenbach. 1980. Fortis versus lenis in Cajonos Zapotec phonology. International Journal of American Linguistics 46. 92-105. https://doi.org/10.1086/465639

Odden, David. 2005. Introducing phonology. Cambridge: Cambridge University Press.

Pérez Báez, Gabriela, Víctor Cata \& Juan José Bueno Holle. 2015. Xneza diidxazá: retos en la escritura del zapoteco del istmo vistos desde el texto teria. Tlalocan 20. 135-172.

Picket, Velma. B., Cheryl Black \& Vicente Marcial Cerqueda. 2001. Gramática popular del zapoteco del Istmo. Segunda edición. Juchitán, Oaxaca, México: Centro de Investigación y Desarrollo Binnizá A.C., Tucson, Arizona: Instituto Lingüístico de Verano A.C.

Picket, Velma. 1951. Nonphonemic stress: A problem in stress placement in Isthmus Zapotec. Word 7. 6065.

Raffelsiefen, Renate. 2005. Paradigm uniformity effects versus boundary effects. In Laura Downing, Tracy Alan Hall \& Renate Raffelsiefen (eds.), Paradigms in phonological theory, 211-262. Oxford: Oxford Univerisity Press.

Sagey, Elizabeth. 1986. The Representation of Features and Relations in Non-Linear Phonology. Cambridge, MA: Massachusetts Institute of Technology dissertation.

Silverman, Daniel. 1997. Laryngeal complexity in Otomanguean vowels. Phonology 14. 235-261. https://doi.org/10.1017/S0952675797003412.

Smith-Stark, Thomas. 2003. Tipos prosódicos de sílabas en el zapoteco de San Baltasar Chichicapan. In Esther Zendejas. \& Pedro Martin Butragueño (eds.), La tonía: dimensiones fonéticas y fonológicas, 111-139. Ciudad de México: El Colegio de México.

Steriade, Donca. 1999. Paradigm Uniformity and the phonetics/phonology boundary. In Janet Pierrehumbert \& Michael Broe (eds.), Papers in Laboratory Phonology Vol. 5, 313-334. Cambridge: Cambridge University Press.

Uchihara, Hiroto. In press. La pérdida de la vocal átona en el zapoteco central. In Francisco Arellanes \& Lilián Guerrero (eds.), Estudios lingüisticos y filológicos en lenguas indígenas mexicanas. Celebración por los 30 años de Seminario de Lenguas Indígenas. Ciudad de México: Instituto de Investigaciones Filológicas, UNAM.

Uchihara, Hiroto \& Ambrocio Gutiérrez. 2019. El texto Don Crescencio: ilustración del sistema tonal del zapoteco de Teotitlán del Valle. Tlalocan XXIV. 127-153.

https://doi.org/10.19130/iifl.tlalocan.2019.487.

Uchihara, Hiroto \& Ambrocio Gutiérrez. In press. Subject and agentivity in Teotitlán Zapotec. Studies in Language (published online in 2020, 1-58). https://doi.org/10.1075/sl.18025.uch. 
Uchihara, Hiroto \& Gabriela Pérez Báez. Fortis/Lenis, glides and vowels in Quiaviní Zapotec. Glossa: $a$ journal of general linguistics 1(1). 27. https://doi.org/10.5334/gigl.13.

Hiroto Uchihara

Instituto de Investigaciones Filológicas

Universidad Nacional Autónoma de México

Circuito Mario de la Cueva,

Ciudad Universitaria, 04510, Ciudad de México

hirotouchihara81@gmail.com
Ambrocio Gutiérrez

Department of Linguistics

University of Texas at Austin

305 E. 23rd Street STOP B5100

Austin, TX 78712

ambrocioteo@utexas.edu 